\title{
EFFEKTIVITAS KOMBINASI CENDAWAN Beauveria bassiana DAN Nomuraea rileyi TERHADAP TINGKAT MORTALITAS HAMA ULAT API JENIS
}

Setothosea asigna

\section{EFFECTIVENESS OF Beauveria bassiana AND Nomuraea rileyi FOOD COMBINATION ON THE LEVEL OF MORTALITY OF PUMP CUTE TYPE Setothosea asigna}

\author{
Saroha Manurung ${ }^{1}$, Dina Arfianti Saragih ${ }^{1}$ dan Andan Kurniawan Sirait ${ }^{1}$ \\ Program Studi Budidaya Perkebunan, Sekolah Tinggi Ilmu Pertanian Agrobisnis Perkebunan \\ (STIP-AP), \\ Jl. Willem Iskandar, Medan 20226 \\ *Corresponding author: sarohamanurung651@gmail.com
}

\begin{abstract}
ABSTRAK
Penelitian dilakukan dengan metode Rancangan Acak Kelompok (RAK) non faktorial yaitu dengan pengamatan langsung di lapangan dengan 5 perlakuan dengan 4 ulangan dengan jumlah 40 ekor Ulat api (P0), 40 ekor ulat api (P1), 40 ekor ulat (P2), 40 ekor ulat api (P3), dan 40 ekor ulat api (P4). dengan beberapa parameter yaitu mengetahui tingkat mortalitas ulat api dengan dosis tertentu dan melihat tingkat laku dari ulat tersebut setelah diaplikasikan terhadap cendawan beauveria bassiana dan Nomuraea rileyi. Hasil penelitian ini menunjukkan bahwa 5 perlakuan dan 4 ulangan yang diteliti, semakin tinggi dosis kombinasi cendawan beauveria bassiana dan Nomuraea rileyi yang diaplikasikan maka tingkat mortalitas kematian ulat juga semakin tinggi, dimana untuk mortalitas tertinggi terdapat pada perlakuan P4 dengan persentase 87,5\% pada hari ke 11 setelah aplikasi dan untuk yang terendah terdapat pada perlakuan PI dengan persentase $77,5 \%$.
\end{abstract}

Key words; Beauveria bassiana, ulat api, hama serangga

\begin{abstract}
The research was conducted using a non-factorial randomized block design (RBD) method with direct observation in the field with 5 treatments with 4 replications with the number 40 fire caterpillars (P0), 40 fire caterpillars (P1), 40 caterpillars (P2), 40 fire caterpillars (P3), and 40 fire caterpillars (P4). with several parameters, namely knowing the mortality rate of fire caterpillars with a certain dose and see the behavior of the caterpillars after being applied to the fungus Beauveria bassiana and Nomuraea rileyi. The results of this study indicate that the 5 treatments and 4 replications studied, the higher the dose of the combination of Beauveria bassiana and Nomuraea rileyi applied, the mortality rate of caterpillar mortality was also higher, where for the highest mortality was found in the P4 treatment with a percentage of $87.5 \%$ on the day The 11th after application and for the lowest is in the PI treatment with a percentage of $77.5 \%$.
\end{abstract}

Key words; Beauveria bassiana, fire caterpillars, insect pest 


\section{PENDAHULUAN}

Kelapa sawit (Elaeis guineensis Jacq.) adalah tanaman perkebunan yang sangat toleran terhadap kondisi lingkungan yang kurang baik. Namun, untuk menghasilkan produksi yang tinggi dibutuhkan kisaran kondisi lingkungan tertentu (disebut juga: syarat tumbuh tanaman kelapa sawit). Faktor lingkungan utama yang mempengaruhi keberhasilan perkembangan tanaman kelapa sawit, yaitu genetis (bahan tanam), perlakuan kultur teknis, kondisi iklim, tanah, dan bentuk wilayah (Sulistyo et al., 2010).

Kelapa sawit mulai dikenalkan di Indonesia pada tahun 1948 oleh pemerintah Belanda. Saat itu, tanaman kelapa sawit dianggap sebagai salah satu jenis tanaman hias. Kebun Raya Bogor (botanical garden) yang dahulu bernama Buitenzorg menanam empat tanaman kelapa sawit, dua berasal dari Bourbon (Mauritius) dan dua lainya dari Hortus Botanicus, Belanda. Pada tahun 1853, tanaman tersebut berbuah dan bijinya disebarkan secara gratis, Keempat tanaman tumbuh subur dan berbuah lebat. Meskipun berbeda waktu penanaman (penanaman tanaman yang berasal dari Bourbon lebih dahulu dua bulan), waktu berbuahnya hampir sama. Kemungkinan besar sumber genetiknya diperoleh dari sumber yang sama (Lubis \& Widanarko, 2011).

Untuk mendapatkan produksi yang optimal, karakteristik dan faktor-faktor yang dapat menghambat produktifitas harus dipahami dan diupayakan solusinya. Salah satu permasalahan penting dalam budidaya tanaman kelapa sawit adalah serangan hama yang dapat menyebabkan kerusakan pada tanaman hingga berdampak pada penurunan tingkat produksi kelapa sawit. Untuk menjamin kepastian hasil usaha perkebunan kelapa sawit, maka kegiatan pengendalian hama merupakan salah satu usaha yang harus dilakukan dalam pemeliharaan (Satriawan, 2011).

Hama-hama yang umum dijumpai menyerang tanaman kelapa sawit adalah Ulat Pemakan Daun Kelapa Sawit (UPDKS). UPDKS terdiri dari ulat api, ulat kantong, dan ulat bulu. Jenis UPDKS yang sering menimbulkan kerugian di perkebunan kelapa sawit antara lain adalah; ulat api adalah dari jenis (Setothosea asigna, Setora nitens, dan Darna trima) dan ulat kantong adalah dari jenis (Metisa plana dan Mahasena corbetti) (Sulistyo et al., 2010).

Serangan hama ulat api mengakibatkan kelapa sawit kehilangan daun yang menyebabkan proses fotosintesa terganggu sehingga fotosintat yang dihasilkan berkurang dan akhirnya berakibat pada penurunan produksi. Apabila kerusakan daun terjadi pada kelapa sawit yang lebih muda, maka kehilangan hasil yang ditimbulkan lebih kecil, tetapi apabila terjadi pada tanaman yang berumur 1-2 tahun kehilangan daun bisa mencapai $50 \%$, sehingga dapat menurunkan produksi sebesar $12 \%-24 \%$ dan $<4 \%$ setelah dua tahun kemudian (Prawirosukorto, 2002 dalam Purba, 2016 ). Maka dari itu perlu dilakukan pengendalian hama ulat api yang baik dan benar serta ramah lingkungan.

Pengendalian hama dapat dilakukan secara kimia dan secara hayati. Pengendalian secara kimia yaitu dengan menggunakan insektisida, sedangkan pengendalian secara hayati dilakukan dengan memanfaatkan musuh (predator) alami dan bioinsektisida. Salah satu insektisida yang bisa kita terapkan dalam mengendalikan hama ulat api adalah dengan menggunakan jamur atau fungi entomopatogen. Fungi entomopatogen 
merpakan jamur yang dapat digunakan sebagai agens pengendalalian hayati untuk mengendalikan serangan hama (Wahyuni, 2017).

Menurut Trizelia (2015) kelompok entomopatogen yang dapat digunakan sebagai agens hayati adalah cendawan entomopatogen. Cendawan entomopatogen yang telah banyak digunakan untuk pengendalian serangan hama secara hayati adalah Beauvaria bassiana (Balsamo) (Trizelia 2015), Metarhizium anisopliae (Metch) (Prayogo et al., 2005), Aspergillus sp. (Nur, 2005, Nomuraea Rileyi (Farlow), Trizelia ,2008.

\section{METODE PENELITIAN}

\section{Tempat dan Waktu Penelitian}

Penelitian ini dilaksanakan di Lahan Sekolah Tinggi Ilmu Pertanian Agrobisnis Perkebunan (STIPAP) Medan. Penelitian dilakukan selama 2 bulan, dimulai dari Mei sampai Juni 2019.

Penelitian ini menggunakan Rancangan Acak Kombinasi (RAK) non faktorial dangan satu faktor yang diteliti, yaitu variasi pemberian bioinsektisida Beauveria bassiana dan N.rileyi dengan dosis berbeda untuk setiap perlakuan, dengan dosis sebagai berikut:

M0 : Perlakuan dengan 2 g Carbaryl 85 SP/1 Aquades

M1 : Perlakuan dengan $2 \mathrm{~g} / 1$ Aquades

M2 : Perlakuan dengan $4 \mathrm{~g} / 1$ Aquades

M3 : Perlakuan dengan $6 \mathrm{~g} / 1$ Aquades

M4 : Perlakuan dengan 8 g/l Aquades

\section{Pengamatan dan Indikator}

Pengamatan tingkat mortalitas hama ulat api secara visual selama 14 hari setelah aplikasi kombinasi cendawan N. Rileyi dan Beuveria bassiana. Pengamatan dilakukan dengan cara menghitung jumlah ulat yang mati dan hidup setiap hari. Persentase mortalitas dihitung dengan rumus :

$$
\mathrm{MT}=\frac{b}{a+b} \times 100 \%
$$

Dimana :

MT $=$ Persentase mortalitas ulat api (Setothosea asigna)

$\mathrm{a}=$ Jumlah ulat api (Setothosea asigna) yang masih hidup

$\mathrm{b}=$ Jumlah ulat api (Setothosea asigna) yang mati

\section{HASIL DAN PEMBAHASAN}

\section{Mortalitas Ulat Api Setothosea asigna}

Berdasarkan hasil analisis data dari pengujian dengan uji DMRT (Duncan Multiple Range test), pada pengamatan 1-2 hari setelah aplikasi (HSA) telah terdapat mortalitas ulat api setothosea asigna, yaitu pada perlakuan P0 (Kontrol) dengan bahan pestisida kimia, sedangkan dengan menggunakan pestisida biologi dengan menggunakan cendawan entomopatogen, Hama ulat api mengalami mortalitas pada 5 HSA, hal itu dapat dilhat pada Tabel 1.

Tabel 1. Persentase Jumlah Mortalitas Ulat Api Setothosea asigna 1-4 HSA.

\begin{tabular}{ccccc}
\hline \multirow{2}{*}{ Perlakuan } & \multicolumn{4}{c}{ Hari Pengamatan Ke $-(\%)$} \\
\cline { 2 - 5 } & 1 HSA & $\mathbf{2}$ & $\mathbf{3}$ & $\mathbf{4}$ \\
& & HSA & HSA & HSA \\
\hline P0 & $62.5 \mathrm{a}$ & $100 \mathrm{a}$ & $100 \mathrm{a}$ & $100 \mathrm{a}$ \\
\hline P1 & $0 \mathrm{~b}$ & $0 \mathrm{~b}$ & $0 \mathrm{~b}$ & $0 \mathrm{~b}$ \\
\hline P2 & $0 \mathrm{~b}$ & $0 \mathrm{~b}$ & $0 \mathrm{~b}$ & $0 \mathrm{~b}$ \\
\hline P3 & $0 \mathrm{~b}$ & $0 \mathrm{~b}$ & $0 \mathrm{~b}$ & $0 \mathrm{~b}$ \\
\hline P4 & $0 \mathrm{~b}$ & $0 \mathrm{~b}$ & $0 \mathrm{~b}$ & $0 \mathrm{~b}$
\end{tabular}


Dari data diatas dapat kita lihat bahwa, pada pengamatan selama 1-4 HSA persentase mortalitas hama ulat api dengan perlakuan $\mathrm{P} 0$, lebih tinggi dan berbeda sangat nyata dibandingkan dengan perlakuan P1, P2, P3 dan P4. Hal ini menunjukkan bahwa pestisida kimia dapat mengendalikan hama lebih cepat dari pada pestisida biologi. Hama ulat api yang terkena pestisida kimia mengalami perubahan warna tubuh menjadi warna coklat lalu berwarna hitam.

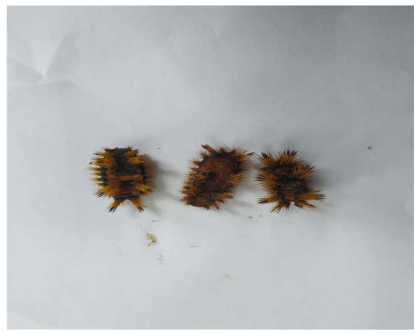

Gambar 1 Ulat Api Setothosea asigna Yang Diaplikasikan Pestisida Kimia (Carbaryl 2 gr).

Dari Tabel 1., dapat dilihat bahwa cendawan kombinasi Beauvaria bassiana dan Nomuraea rileyi membutuhkan waktu yang cukup lama untuk menginfeksi tubuh ulat api, sebagaimana yang dinyatakan oleh (Deciyanto et al., 2015 dalam Turnip et al., 2018) bahwa jamur entomopatogen B.bassiana berkecambah sampai 2 hari, kemudian menumbuhkan miselia dalam tubuh inang sehingga serangga yang terinfeksi pada 3 sampai 5 hari. Serangga terinfeksi mati dengan ditandai adanya pertumbuhan konidia pada integumen.

Mortalitas hama ulat api dengan perlakuan kombinasi cendawan B.bassiana dan N.rileyi dimulai pada 5 HSA, yaitu pada perlakuan P1, P2, P3 dan P4. Ulat yang mati memiliki ciri-ciri yaitu, tubuh ulat berubah menjadi warna hijau pucat kekuningan, dan mengkerut. Hal tersebut disebabkan cendawan telah melakukan infeksi dan berkembang ditubuh ulat.
Menurut (Herlinda et al., 2008, dalam Sihombing et al., 2014), waktu yang dibutuhkan untuk menyebabkan kematian serangga uji bervariasi tergantung pada virulensi patogen, sifat ketahanan inang, dan kondisi lingkungan mikro di tubuh inang.

Perlakuan P1, P2, P3 dan P4 mengalami mortalitas pertama pada 5 HSA, dengan persentase mortalitas P1 5\%, P2 sebesar $10 \%$, P3 sebesar $12.5 \%$ dan P4 sebesar $22.5 \%$, dimana ciri ciri hama ulat api yang mati ditandai dengan perubahan warna tubuh. Perubahan warna tubuh ulat dengan perlakuan cendawan entomopatogen $B$. bassiana lokal ditandai dengan perubahan warna tubuh yang awalnya berwarna hijau kemudian berubah menjadi hijau pucat. Pada ulat api yang masih hidup, terjadi perubahan warna tubuh dan tingkah laku ulat. Perubahan tingkah laku ulat setelah diaplikasikan kombinasi cendawan $B$. bassiana dan N.rileyi yaitu, pergerakan mulai lambat, aktivitas ulat menurun, serta pada beberapa ulat warna tubuh ulat mulai berubah menjadi warna hijau pucat Kekuningan.

Pada 5 HSA, mortalitas hama ulat api relatif kecil, dimana $\mathrm{P} 4$ memiliki persentase terbesar dengan persentase $22.5 \%$, serta P1 memiliki persentase terkecil dengan yakni 5\%. Selama pengamatan 5-8 HSA, perlakuan P0 berbeda sangat nyata dengan perlakuan P1, P2, P3 dan P4, sedangakan perlakuan P1, P2, P3 dan P4 masing masing tiap perlakuan mengalami perbedaan yang nyata dan ada yang tidak berbeda nyata juga. hal tersebut dapat dilihat pada Tabel 2 . 
Tabel 2. Persentase Jumlah Mortalitas Hama Ulat Api Setothosea asigna 5-8 HSA

\begin{tabular}{ccccc}
\hline \multirow{2}{*}{ Perlakua } & \multicolumn{4}{c}{ Hari Pengamatan Ke $-(\%)$} \\
\cline { 2 - 5 } n & $\mathbf{5}$ & $\mathbf{6}$ & $\mathbf{7}$ & $\mathbf{8}$ \\
& HS & HS & HS & HS \\
& $\mathbf{A}$ & $\mathbf{A}$ & $\mathbf{A}$ & $\mathbf{A}$ \\
\hline P0 & $100 \mathrm{a}$ & $100 \mathrm{a}$ & $100 \mathrm{a}$ & $100 \mathrm{a}$ \\
\hline P1 & $5 \mathrm{c}$ & 12.5 & $25 \mathrm{c}$ & 42.5 \\
& & $\mathrm{c}$ & & $\mathrm{c}$ \\
\hline P2 & $10 \mathrm{~b}$ & 17.5 & $30 \mathrm{c}$ & 47.5 \\
& & $\mathrm{c}$ & & $\mathrm{c}$ \\
\hline P3 & 12.5 & $20 \mathrm{~b}$ & $30 \mathrm{c}$ & 47.5 \\
& $\mathrm{~b}$ & & & $\mathrm{c}$ \\
\hline P4 & 22.5 & 27.5 & 42.5 & $55 \mathrm{~b}$ \\
& $\mathrm{~b}$ & $\mathrm{~b}$ & $\mathrm{~b}$ &
\end{tabular}

Data pada Tabel 2., terlihat bahwa mortalitas hama ulat api Setothosea asigna dengan perlakuan kombinasi cendawan $B$. Bassiana dan N. Rileyi terus meningkat sampai pada 8 HSA. Hal ini dapat kita lihat dalam grafik berikut ini :

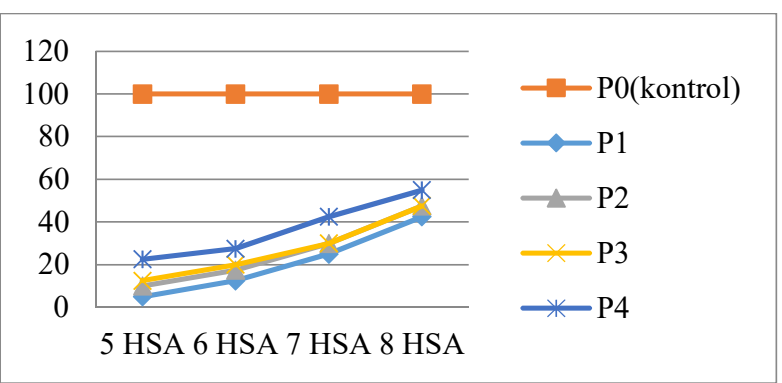

Gambar 2. Grafik Persentase Mortalitas Hama Ulat Api Setothosea asigna Pada 5-8 HSA

Peningkatan persentase mortalitas hama ulat api dengan perlakuan kombinasi cendawan B. Bassiana dan N. Rileyi yang tidak signifikan terjadi karena cendawan yang masuk kedalam tubuh ulat membutuhkan waktu untuk bisa menginfeksi dan mematikan ulat api. Hal ini dapat kita lihat dari tidak serentaknya ulat yang mati, dan jumlah ulat api yang mati setiap hari bertambah walaupun dalam jumlah yang sedikit, serta perubahan warna tubuh ulat yang berwarna kekuningan atau mengkerut dan tubuh ulat yang lambat bergerak.

Wowiling $\mathrm{S}$ et al., (2015), menyatakan bahwa waktu yang dibutuhkan untuk menyebabkan kematian inang ditentukan oleh berbagai faktor, diantaranya adalah virulensi pathogen, sifat resistensi inang, serta kondisi lingkungan yang membantu infeksi dan pertumbuhan patogen. Perkecambahan dan pertumbuhan serta sporalisasi optimum fungi $\quad B$. Bassiana terjadi pada suhu $25-30{ }^{\circ} \mathrm{C}$ dan kelembapan relative $100 \%$ sehingga diperlukan suhu dan kelembaban yang cukup agar fungi patogen dapat berkembang biak dengan baik (Ahmad 2008). Namun demikian, jamur ini juga memiliki fase resisten yang dapat mempertahankan kemampuannya menginfeksi inang pada kondisi kering. Keberadaan epizootiknya di alam menyebabkan B. Bassiana secara cepat dapat menginfeksi populasi serangga hingga menyebabkan kematian (Soetopo \& Indrayani, 2007).

Indarayani (2011) menyatakan bahwa pada umumnya, persyaratan tumbuh fungi memerlukan suhu dan kelembaban yang tinggi dalam hidupnya, demikian juga dengan Fungi $N$. Rileyi perkembangan hidupnya membutuhkan kelembaban tinggi $(80-90 \%)$ terlebih lagi dalam proses perkecembahan dibanding dengan kelembapan rendah $(<60 \%)$, terutama untuk melakukan kontak dengan kutikula serangga. Sebaliknya, untuk pembentukan konidia dan melakukan penyebaran secara horizontal pada inang lain biasanya terjadi pada kelembaban lingkungan yang lebih rendah (50-60\%). Pada kelembapan tinggi miselium 
N. Rileyi akan tumbuh dari ulat yang telah memufikasi dan memproduksi konidiofor sebagai alat invasi ke seluruh bagian internal serangga.

Pada pengamatan ulat yang mati tidak dijumpai hama ulat api yang diselimuti oleh miselium ataupun konidia cendawan, namun ulat yang mati berwarna hijau pucat kekuningan, lalu pengalami pengkerutan, dan kemudian terjadi mumufikasi (tubuh akan mengeras) serta warna tubuh berubah menjadi kusam dan menjadi warna kecoklatan. Hal ini sesuai dengan yang telah dijelaskan oleh Plate (1976), serangga yang mati tidak selalu disertai gejala pertumbuhan spora. Contohnya aphid yang terinfeksi B.bassiana hanya mengalami pembengkakan tanpa terjadi perubahan warna. Demikian pula tempayak lalat yang terinfeksi B.bassiana sering ditemukan secara belompok pada ujung ujung rerumputan. Lebih lanjut Soetopo \& Indrayani (2007) melaporkan bahwa serangga yang terbunuh, tubuhnya akan berwarna putih karena ditumbuhi konidia B.bassiana dan menurut Indrayani (2011) larva yang terinveksi N.rileyi biasanya menunjukkan gejala "mumifikasi" atau pengerasan yang diikuti dengan pertumbuhan miselium pada seluruh permukaan tubuhnya. Konidiofor yang terbentuk dari miselium memproduksi konidia yang warnanya hijau kekuningan atau biru kehijauan.

(a)

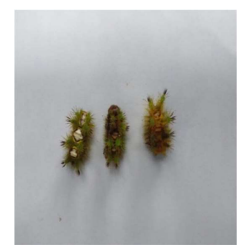

(b)

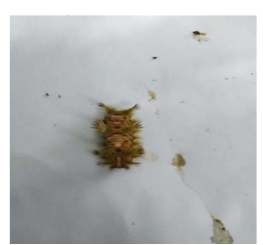

Keterangan Gambar 3 :

(a) Tubuh ulat api Setothosea asigna mulai kaku pada 1 hari setelah mati (HSM). (b) Tubuh ulat api Setothosea asigna mulai mengkerut dan berubah warna menjadi hijau kekuningan pada $2 \mathrm{HSM}$

(c) Tubuh ulat api mulai mengeras pada 4 HSM .

Hasil pengamatan juga ditemukan ulat api yang mati dalam keadaan tubuh mengempis dan warna tubuhnya pucat kekuning kuningan. Dimana hama ulat api tersebut kehilangan cairan tubuhnya, yang disebabkan larva tidak mau makan sehingga ulat tersebut mati. Hal ini sesuai dengan pernyataan Soetopo \& Indrayani (2007) bahwa serangga yang terinfeksi gerakanya lamban, nafsu makannya berkurang bahkan berhenti sama sekali, sehingga lama kelamaan diam dan mati serta tubuh serangga yang terinfeksi tersebut berubah menjadi pucat, seperti yang terlihat pada Gambar 4 .

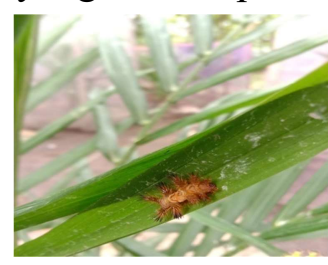

Gambar 4. Hama Ulat Api Setothosea asigna Kehilangan Cairan dan Mengkerut

Berdasarkan pengamatan pada 9-11 HSA persentase mortalitas hama ulat api setothosea asigna terus meningkat. Ini menunjukkan bahwa semakin lama jumlah ulat yang mati semakin meningkat. Hama ulat yang mati memiliki ciri ciri yang berbeda, seperti, warna tubuh berubah menjadi hijau pucat kekuningan dan pucat serta berubah coklat kehitaman, tubuh mengkerut, serta tubuh ulat kehilangan cairan. Persentase kematian ulat yang mendapat perlakuan kombinasi cendawan B.bassiana dan N.rileyi pada 9 HSA yang tertinggi berada pada P4 yakni dengan persentase $67.5 \%$ dan yang paling kecil yakni pada $\mathrm{P} 1$ sebesar $50 \%$ dan selisih persentase mortalitas antar setiap perlakuan P1 sampai P4 tidak terlalu jauh. Pada pengamatan 11 
HSA, persentase mortalitas hama ulat api tertinggi berada pada $87.5 \%$ yakni perlakuan P4. Dan persentase mortalitas yang terendah berada pada $77.5 \%$, yakni perlakuan $\mathrm{P} 1$, Untuk perlakuan P2 dan P3, persentase mortalitas yang didapat adalah untuk perlakuan P2 sebesar $77.5 \%$ dan untuk P3 yakni sebesar $82.5 \%$, kita dapat melihatnya dari tabel dibawah ini.

Tabel 3. Persentase Jumlah Mortalitas Ulat api Setothosea asigna 9-11 HSA

\begin{tabular}{cccc}
\hline \multirow{2}{*}{$\begin{array}{c}\text { Perlakua } \\
\mathbf{n}\end{array}$} & \multicolumn{3}{c}{$\begin{array}{c}\text { Hari } \\
\text { Pengamatan }\end{array}$} \\
\cline { 2 - 4 } & $\begin{array}{c}\mathbf{9} \\
\text { HSA }\end{array}$ & $\begin{array}{c}\mathbf{1 0} \\
\text { HSA }\end{array}$ & $\begin{array}{c}\mathbf{1 1} \\
\text { HSA }\end{array}$ \\
\hline $\mathrm{P} 0$ & $100 \mathrm{a}$ & $100 \mathrm{a}$ & $100 \mathrm{a}$ \\
\hline $\mathrm{P} 1$ & $55 \mathrm{c}$ & $72.5 \mathrm{~d}$ & $\begin{array}{c}77.5 \\
\mathrm{c}\end{array}$ \\
\hline $\mathrm{P} 2$ & $62.5 \mathrm{~b}$ & $75 \mathrm{c}$ & $\begin{array}{c}77.5 \\
\mathrm{c}\end{array}$ \\
\hline $\mathrm{P} 3$ & $62.5 \mathrm{~b}$ & $77.5 \mathrm{c}$ & $\begin{array}{c}82.5 \\
\mathrm{~b}\end{array}$ \\
\hline $\mathrm{P} 4$ & $67.5 \mathrm{~b}$ & $77.5 \mathrm{~b}$ & $\begin{array}{c}87.5 \\
\mathrm{~b}\end{array}$ \\
\hline
\end{tabular}

Dari tabel 3., tersebut, kita dapat melihat bahwa setelah pengamatan selama 11 hari, jumlah hama ulat api yang mati antara perlakuan P0 (kontrol) dengan P1, P2, P3 dan P4 terjadi selisih persentase mortalitas yang sangat jauh dan berbeda nyata. Dimana perlakuan P0 mencapai persentase mortalitas $100 \%$ sedangkan perlakuan P1, P2, P3 dan P4 mencapai tingkat persentase mortalitas tertinggi hanya pada $\mathrm{P} 4$ dengan persentase $87.5 \%$.

Tidak tercapainya mortalitas hama ulat api Setothosea asigna selama 11 hari pengamatan dengan perlakuan kombinasi cendawan $B$. bassiana dan $N$. rileyi dengan tingkat dosis yang berbeda tiap perlakuannya. Kemungkinan dipengaruhi umur ulat yang semakin bertambah, sehingga kekebalan hama ulat api meningkat.

Berdasarkan hasil sidik ragam menunjukkan bahwa, perlakuan beberapa dosis kombinasi cendawan $B$. bassiana dan $N$. rileyi serta perlakuan pestisida kimia (Carbaryl 85 SP) (kontrol) berpengaruh nyata terhadap jumlah mortalitas hama ulat api Setothosea asigna dapat dilihat seperti yang tersaji pada Tabel 4:

Tabel 4. Total Persentase Jumlah Mortalitas Hama Ulat Api Setothosea asigna pengamatan selama 11 hari

\begin{tabular}{cc}
\hline Perlakuan & Rata - rata \\
\hline P0 (kontrol) & $100 \mathrm{a}$ \\
P1 & $77.5 \mathrm{c}$ \\
P2 & $77.5 \mathrm{c}$ \\
P3 & $82.5 \mathrm{~b}$ \\
P4 & $87.5 \mathrm{~b}$ \\
\hline
\end{tabular}

Dari data pada Tabel 4. dapat kita lihat bahwa selama pengamatan 11 hari, total ratarata mortalitas hama ulat api Setothosea asigna, dimana :

1. Perlakuan P1 dengan dosis kombinasi cendawan $B$. bassiana dan $N$. rileyi $2 \mathrm{~g} / 1$ air, tidak berbeda nyata dengan perlakuan P2 dengan dosis 4 gr/l air.

2. $\mathrm{P} 2$ berbeda nyata dengan $\mathrm{P} 3$ dengan dosis $6 \mathrm{~g} / 1$ air.

3. P3 tidak berbeda nyata dengan P4 dengan dosis $8 \mathrm{~g} / 1$ air.

4. P4 berbeda nyata dengan P0 (kontrol) yang menggunakan pestisida kimia Carbaryl 85 SP dengan dosis $2 \mathrm{~g} / 1$ air.

\section{KESIMPULAN}

Berdasarkan hasil penelitian ini dapat ditarik kesimpulan yaitu bahwa dosis yang paling efektif untuk mengendalikan ulat api 
Setothosea asigna adalah $8 \mathrm{~g} /$ liter air dengan tingkat mortalitas $87.5 \%$.

\section{DAFTAR PUSTAKA}

Ahmad, R. Z. 2008. Pemanfaatan Cendawan untuk Meningkatkan Produktivitas dan Kesehatan Ternak. J Litbang Pert 27(3): 86.

Harahap, P. R. 2018. Efektifitas Ekstrak Buah Mengkudu (Morinda Citrifolia L) Terhadap Mortalitas Ulat Api (Setothosea Asigna) Pada Tanaman Kelapa Sawit (Elaeis Guineensis Jacq). Tugas akhir. Sekolah Tinggi Ilmu Pertanian Agrobisnis Perkebunan, Medan

Hidayah, N dan Indrayani, I,G,A,A. 2011. Pengaruh Komposisi Media Terhadap Pertumbuhan jamur Nomuraea rileyi (FARLOW) SAMSON dan Patogenitasnya Pada Helicoverpa armigera HUBNER dan Spodoptera litura F. JURNAL LITTRI Vol 17 No 3 Hal 102-108. Balai Penelitian Tanaman Tembakau dan Serat. Malang.

Indrayani, IGAA. 2011. Potensi jamur Entomopatogen Nomuraea rileyi (FARLOW) Samson untuk Pengendalian Helicoverpa Armigera hubner pada Kapas. Balai Penelitian Tanaman Tembakau dan Serat Indonesian Tobacco and Fibre Crops Research Institute

Lubis, R. E, dan Agus Widanarko. 2011. Buku Pintar Kelapa Sawit PT. AgroMedia Pustaka. (Cetakan ke-2) Jakarta.

Nur M. 2005. Isolasi, Identifikasi, dan Uji Patogenisitas Jamur Entomopatogen dari Larva Heliothis armigera Hubner. Pendidikan IPA. Digital Library UPI
SSCA Wowiling, J Pelealu, RTD Maramis, 2015 Pemanfaatan Cendawan Beauveria bassiana dalam Mengendalikan Hama Paraeucosmetus sp. Pada Tanaman Padi Sawah di Kabupaten Minahasa Selatan (The Use of Endophytic Fungi Beauveria bassiana to Control Paraeucosmetus sp. on Rice Plant in South Minahasa Dist.JURNAL BIOS LOGOS.

Sulistiyo, B, DH. Abubakar, S. Amir, P. Donald, S. Johan, E. 2010. Budi Daya Kelapa Sawit . Balai Pustaka. Jakarta.

Satriawan, R. 2011. Kelimpahan Populasi Ulat Api Dan Ulat Kantung, Serta Predator Pada Perkebunan Kelapa Sawit.IPB.Sulistyo， B. 2010.Budidaya Kelapa Sawit. Pusat Penelitian Kelapa Sawit. PPKS, Medan.

Sihombing, R., Oemry . S dan Lubis L. 2014. Uji Efektivitas Beberapa entomopatogen pada larva Oryctes rhinoceros L. (coleoptera Scarabaeadae) di Laboratorium. Jurnal Online Agroteknologi, Vol 2,No,4, Universitas Sumatera Utara. Medan.

Soetopo, D., dan Indrayani. 2007. Status Teknologi Dan prospek Beauveria bassiana Untuk Pengendalian Serangan hama Tanaman Perkebunan Yang Ramah Lingkungan. Balai penelitian Tanaman Tembakau dan Serat. MalangJawa timur.

Plate, J. 1976. Fungi. Biological Control: A guide to natural enemies in North America. Cornel University.4pp

Prayogo, Y. dan Suharsono. 2005. Optimalisasi

Pengendalian Hama Pengisap Polong Kedelai (Riptortus linearis) dengan 
Cendawan Entomopatogen Verticillium lecanii. Jurnal Litbang Pertanian 24 (4): 123-130.

Turnip, A., Dirky, Y, P, R. Daniel, L. 2015. Uji Efektivitas Jamur Beauveria bassiana dan Waktu Aplikasi Terhadap Hama Spodoptera litura Pada Tanaman Sawi Hijau (Brassica juncea).

Trizelia, Neldi Armon, dan Hetrys jailani. 2015. Keanekaragaman Jamur Entomopatogen pada Rizosfer Berbagai Tanaman Sayuran, PROS SEM NAS MASY BIODIV INDON Vol 1 No 5 Hal 998-1004. Program Studi Agroekoteknologi, Fakultas Pertanian, Universitas Andalas, Kampus Limau manih, Padang.

Trizelia. 2008. Patogenisitas cendawan entomopatogen Nomuraea rileyi (Farl.) Sams. Terhadap hama Spodoptera exigua Hubner (Lepidoptera:Noctuidae). Jurnal Entomologi Indonesia 5(2):108-115. 